\title{
Pro-poor Tourism: a New Tourism Policy in China for Poverty Alleviation
}

\author{
Wei YANG, Sukanya Aimimtham, Chuanchen BI
}

\begin{abstract}
Poverty reduction is now a major issue for developing countries to focus on and whose success, or otherwise, will directly affect upon the achievement of development of the nation. China has made significant advances in poverty reduction since the launch of its reform and open policy in 1978, however, the poverty issue is still obviously present. The Central government of China launched a new strategic plan for poverty alleviation called 'precision poverty alleviation' in 2015. It is aimed at taking targeted measures for poverty alleviation. Moreover, most of the poverty regions overlap the famous tourism resources, which offer the best opportunity for the tourism industry to be involved in this new poverty alleviation strategy. This paper mainly focusses on pro-poor tourism as a new tourism policy for precision poverty alleviation. Specifically, this paper is divided into three themes based on the focus topic. The first theme overviews poverty alleviation in China, the processing period and the gap between the previous strategy and the poverty alleviation situation. The second theme describes the importance of pro-poor tourism for precision poverty alleviation, and explores the development model. The last theme offers academic discussion and future predictions related to this new tourism policy for precision poverty alleviation in China.

Key words: Pro-Poor Tourism, Tourism Policy, Precision Poverty Alleviation, China.
\end{abstract}

\section{INTRODUCTION}

Throughout human development, the poverty issue has been most serious and prodigious around the world; finding a solution will directly impact on the development of human beings. In the 1940s, the UN announced that poverty alleviation was the most serious issue of concern for the coming new century. However, after almost 70 years have passed, the poverty issue retains its 'serious' status in the world. According to a UN report, over 1.3 billion of the world's population is still below the UN poverty line that is their average spending is lower than $\$ 1.5$ per day. Almost 18 million people die due to poverty. In China, as the biggest developing country, the poverty issue is also serious. Luckily, the poverty issue retains a serious status in China. The government still utilizes their full efforts in trying to solve the problem. An overview of the Chinese poverty area indicates that, due to its location far away from the urban areas, transportation accessibility is low, though the natural resources and cultural diversity have been well conserved. In

Revised Manuscript Received on October 22, 2019.

Wei YANG, Faculty of Humanities and Social Sciences, International College, Khon Kaen University, Khon Kaen, Thailand

Assoc. Prof. Dr. Sukanya Aimimtham, Public Administration Department, Faculty of Humanities and Social Sciences, Khon Kaen University, Khon Kaen, Thailand.

Dr. Chuanchen BI, Tourism Management Department, International College, Khon Kaen University, Khon Kaen, Thailand the western part of China, over $80 \%$ of the poverty area overlaps with natural, national parks or culturally conserved areas. Out of $70 \%$ of the tourism attractions in China, almost $50 \%$ are located in poor, rural areas. All these indicate the great opportunities for utilizing the tourism industry as a method to achieve the poverty alleviation goal in China. (huanfeng, 2017; Tie, 2008)

\section{CHINA POVERTY SITUATION}

China is categorized as the one of the largest territories in the world. This provides different cultural and social development processes throughout the various regions; however, China has the largest poverty stricken population in the world's record. In order to achieve the MDG from the UN, the Chinese government has used various policies to support poverty alleviation since the 1970s as the followings. (huanfeng, 2017; Li Zhou, 2004) 1978-1985, this period was considered to be the first period for the Chinese government to try to solve the poverty issue. In 1982, the Chinese central government nominated one region, consisting of two states named Gansu province and Ningxia Hui Autonomous Region, as the pilot project. This initial project achieved a great outcome, the poor population was reduced from 250 million to 125 million. 1986-1993, after the pilot project, the Chinese central government created a special team 'Economic development team for the poverty region' to lead the national poverty alleviation drive. This team offered several policies which included tax free, free education, technical support and others to assist the poor population inpoverty alleviation. During this period, the poor population reduced from 125 million to 80 million in the whole of China. 1994-2000, in this period, the Chinese central government set up 592 national poverty districts, which planned to solve the poverty issue before the year 2000 . During this period, the poor population was reduced to 30 million. 2001-2012, this was the most successful period for poverty alleviation in China. After China became a member of the World Trade Organization (WTO), this contributedto reducing the poor regions along the coast line.

2013- Present, President Xi, announced a new policy to help the Chinese poor population to get out of the poverty situation in 2013. The new policy was named 'precision poverty alleviation'. The main purpose of 'precision poverty alleviation' is to use the strength of each industry to help the poor regions to achieve the UN MDG. 


\section{Pro-poor Tourism: a New Tourism Policy in China for Poverty Alleviation}

\section{PRO-POOR TOURISM AS THE POLICY}

Pro-poor tourism was announced in 1999. This was the first time that it was announced to the world that tourism could help in contributing topoverty alleviation in the world(C. M. J. C. I. i. T. Hall, 2007). Pro-poor tourism refers to tourism that is developed in a way that furthers the cause of poverty alleviation. It has been defined simply as "tourism that results in increased benefits for poor people" (Pro-Poor Tourism Partnership, 2004). This same source classifies strategies for pro-poor tourism in terms of the type of local benefits achieved: "1) economic, 2) other livelihood benefits (such as physical, social or cultural), and 3) less tangible benefits". Referring to a three-faceted understanding of poverty of money, poverty of access and poverty of power, ESCAP declared that planners and policy makers in tourism must define the task of poverty alleviation through tourism as being broader than simply raising the income levels above the poverty line for the greatest number of people (ESCAP, 2003).The body of literature on pro-poor tourism is relatively new(Suntikul, Bauer, \& Song, 2009). In the late 1990s, a Department for Economic Development document (DFID, 1999) remarked on the dearth of attention to this topic. In tourism discourse at the time of its publication. (C. M. Hall, 2007)chronicled the evolution of thinking on the relationship between tourism and poverty. This is from the 1950s paradigm of tourism as a modernizing factor that intrinsically benefited the poor of developing countries. Through discourses of the disenfranchisement of the poor from tourism that were prevalent in the 1970s and 1980s, to a renewed belief, in the 1990 s, of the potential for tourism in poverty alleviation, albeit with a focus on bottom-up local initiatives rather than by top-down 'modernization' schemes.

Frameworks for pro-poor tourism have been emerging over the past decade. Roe gives a summary of the conceptual and historical bases of pro-poor tourism, and discusses in detail the roles of different stakeholders - including the poor themselves as well as businesses, government and NGOs. He also provides a critical assessment of what can be done by these different stakeholders to support the success of pro-poor tourism(Ashley, Roe, \& ODI, 2002). The Pro-Poor Tourism Partnership (PPT) is a cooperative research initiative of the International Centre for Responsible Tourism (ICRT), the International Institute for Environment and Development (IIED), and the Overseas Development Institute (ODI), responsible for much of the groundbreaking work in establishing research into pro-poor tourism(Ashley \& Roe, 2001). The Pro-Poor Tourism Partnership has also published an Annual Register tracking developments in this type of tourism over the previous year. As described by Mowforth and Munt, pro-poor tourism is an outgrowth of the broadening scope of the idea of sustainable tourism to encompass socio-cultural, economic, as well as environmental sustainability(Fennell, Woodward, Mitchell, Pickles, \& of tourism for poverty alleviation within the broader endeavors of sustainable tourism and discusses the links between the environmental, socio-cultural and economic aspects of sustainable tourism. Conformity, 2005). Yunis (2004) articulates the importance

\section{A. Tourism as the tool}

As previously indicated, an overview of the Chinese poverty area, due to its location being far away from the urban areas, indicates transportation accessibility to be low, with the natural resources and cultural diversity being well conserved. In the western part of China, over $80 \%$ of the poverty area overlaps with either natural national park or culturally conserved areas. Among $70 \%$ of the tourism attractions in China, almost $50 \%$ of them are located in poor rural areas. All these indicate a great opportunity for using the tourism industry as the tool to achieve the poverty alleviation goal in China.Since the Chinese central government sets their poverty alleviation policy, the tourism industry has been treated as great contributor towardspoverty alleviation in the country. After using tourism as the tool for poverty reduction, some impacts have been found (huanfeng, 2017; shuqi, 2001):Fullutilization of the tourism resources in the poverty regions, and well conserved tourism resources in the poverty area.Tourism industry is acomprehensive industry which includes accommodation, restaurants, entertainment, etc.Once applied in the poverty regions, it could offer more jobs for the local residents.Improvement of the local incomes, improvement to the local living standard.Able to modify the local industrial structure, improve the local eco-environment, make the local economy more sustainable.Improve the quality of local labor and also improve the local cultural/spiritual environment.Able to improve the local facilities and open up for urbanization. However, some the negative impactsfrom tourism might also occur. As poverty status is the greatestconcern for poverty alleviation, some of the efforts might also be limited by this poverty status, such as a lack of financial support, supply chain, and talented experts, which will createdifficultiesin achieving the poverty alleviation goals. Some of the other negative impacts might include damage to the local environment, local corruption, etc

\section{B. Pro Poor Tourism as a policy for precision poverty alleviation in China}

As the tourism industry has served Chinese poverty alleviation for some decades, negative impacts have occurred, continually. Especially after President $\mathrm{Xi}$ mentioned 'precision poverty alleviation' in China;a suitable way to use the tourism industry for poverty alleviation needs to be seriously considered(shuqi, 2001; Tie, 2008). Pro-poor tourism is different from other ways of using tourism for poverty alleviation as it focuses particularly on 'bringing net income for the poor'(Bowden, 2005), and 'guaranteeing the tourism development contributestopoverty alleviation, especially promotingthe conservation ofthe economy, society, and the environment(Scheyvens, 2009)', etc. The core of pro-poor tourism is to help the poor get a net income, rather than to expand the tourism industry in to the poor areas(Ashley et al., 2002). Pro-Poor tourism is neither a special tourism product, nor a tourism department, it is a true method to improve how poor people get benefit.

Published By: 
The strategic focus of pro-poor tourism is to let the poor achieve economic benefit, to provide surviving skills and an opportunity to be part of the decision making. As concluded, pro-poor tourism is a platform supporting the national policy of using strategic planning in order let the local residents participate in the tourism system. From a theoretical view, pro-poor tourism connects with sustainable tourism development. Especially, it connects with the three dimensions of sustainable tourism development, which are economic, socio-cultural, and environmental. Moreover, pro-poor tourism focuses on equality. This equality ensuresthat the local residents share the local resources with the different stakeholders, such as the government, tourists, tourism operations, tourism companies, etc.

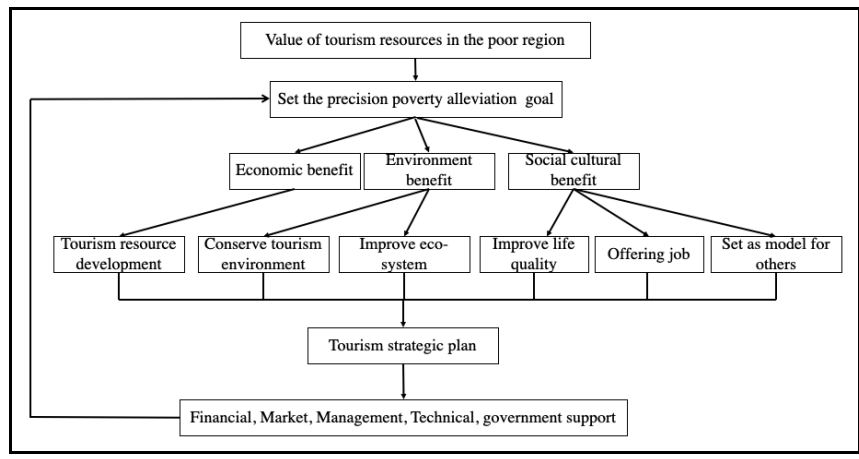

Figure 1 Theoretical framework of pro-poor tourism as policy for precision poverty alleviation in China by author

As indicated above, most of the poor regions are located in the rural areas, while most of the rural areas overlap the tourism resources. The model under pro-poor tourism is explored as below,

\section{Company + local community model}

Company, this is specifically a company that focuses on tourism development, tourism promotion, and tourism attraction management. Under China's current situation, Tourism Companieshave two categories, 'State owned Enterprise' and 'Private Tourism Company'. These offer financial support to operate tourism activities and maintain tourism construction, upgrade community public facilities and hire local villagers be a part of their tourism activities.These are the major operating methodsof a tourism company. State Owned Enterprises (will use SOE instead), due to the government background, they have more advantages in dealing with the tourism attractions. Moreover, the advantage for this SOE tourism company is in policy support, such as tax-free. Tourism attraction reconstruction, updates totourism facilities and applying for a special budget are easier. With the government involved with the Tourism Company, it will benefit from development as a tourism attraction under government supervision. With support from government, the tourism attraction could expand market awareness to attract more tourists. For the second category of 'Tourism Company', Private Tourism Company (will use PTC instead) also plays an important role in tourism management of rural areas in China, such as Xishuangbanna, China (XSBN). As XSBN was one of the first tourism destinations in China, tourism has beenoperated there for over 50 years.To better stimulate the tourism development in XSBN, the local government set some policies to encourage and guarantee private tourism companies involved in tourism management. Compared with the SOE, PTC is more fixable in applying and using theirfinancial budget. For the villagers, specifically the ones who stay inside the ethnic community of the XSBN area, they offer landscapes, their traditional buildings asa tangible museum, the natural environment, traditional way of life, historical Theravada Buddhism religion, and colorful ethnic culture as the background for a Tourism Company to operate tourism related activities. The research by scholarsand tourism income evidence suggest that this 'Company + Villagers Management' approach is the most successful operating experience in ethnic cultural tourism and rural tourism in China. It also contributes to the local residents' income and quality of life(Chuanchen, Yongvanit, \& Thawornwiriyatrakul, 2016).

\section{CONCLUSION}

As pro-poor tourism is quite a new thing matched with precision poverty alleviation in China, this paper mainly states the importance of pro-poor tourism, and the difference between pro-poor tourism and other methods of tourism for poverty alleviation in China. Pro-poor tourism has been applied in several developing countries, such as Turkey, Malaysia, South Africa, etc.The greatest achievement offered is the evidence for other developing countries to apply this method of poverty alleviation(Ab.Hadi, Roddin, Razzaq, Mustafa, \& Baser, 2013; Pillay \& Rogerson, 2013; Zarandian, Shalbafian, Ryan, \& Amin Bidokhti, 2016; Zeng \& Ryan, 2012). Moreover, the China poverty situation as mentioned, is overlapped with the tourism resource region, which offer the great opportunity for using tourism as the tool for achieving the poverty alleviation in China. By the last part of this paper, one model with the name of 'company + local community' appears as the one attempt for the offering the benefit from tourism to pro poor, which need to draw scholars attention.

\section{REFERENCES}

1. Ab.Hadi, M. Y., Roddin, R., Razzaq, A. R. A., Mustafa, M. Z., \& Baser J. A. ( 2013). Poverty Eradication through Vocational Education (Tourism) among Indigenous People Communities in Malaysia: Pro-poor Tourism Approach (PPT). Procedia - Social and Behavioral Sciences, 93, 1840-1844. doi:https://doi.org/10.1016/j.sbspro.2013.10.127

2. Ashley, C., \& Roe, D. (2001). Pro-poor tourism strategies: Making tourism work for the poor: A review of experience: lied.

3. Ashley, C., Roe, D. J. O., \& ODI, E. f. T. D. P. (2002). Working with the private sector on pro-poor tourism.

4. Bowden, J. J. A. P. J. o. T. R. (2005). Pro-poor tourism and the Chinese experience. 10(4), 379-398.

5. Chuanchen, B. I., Yongvanit, S., \& Thawornwiriyatrakul, W. (2016). New trends of mass tourism management in PR. China, case study of xishuangbanna dai autonomous prefecture. International Journal of Applied Business and Economic Research, 14(11), 7515-7536.

6. Fennell, D. A., Woodward, R., Mitchell, K., Pickles, K., \& Conformity, C. J. T. C. G. L. G. c. (2005). Tourism and Sustainability: Development and New Tourism in the Third World (2d ed.), by Martin Mowforth and Ian Munt. 49(4), 411-419. 
7. Hall, C. M. (2007). Pro-poor tourism: who benefits?: perspectives on tourism and poverty reduction (Vol. 3): Channel View Publications.

8. Hall, C. M. J. C. I. i. T. (2007). Pro-poor tourism: Do 'tourism exchanges benefit primarily the countries of the South'?, 10(2-3), 111-118.

9. huanfeng, D. (2017). Research on tourism industry for poverty deduction in China. Tourism Academic.

10. Li Zhou, C. J. (2004). The Impact of Tourism industry towards to Rural area and farmer in China: China Agricultural Press.

11. Pillay, M., \& Rogerson, C. M. (2013). Agriculture-tourism linkages and pro-poor impacts: The accommodation sector of urban coastal KwaZulu-Natal, South Africa. Applied Geography, 36, 49-58. doi:https://doi.org/10.1016/j.apgeog.2012.06.005

12. Scheyvens, R. J. T. r. r. (2009). Pro-poor tourism: Is there value beyond the rhetoric?, 34(2), 191-196.

13. shuqi, Y. (2001). Applying PPT as the poverty deduction policy in Fujian Province. Human Geography, 16(6), 47-49.

14. Suntikul, W., Bauer, T., \& Song, H. J. A. p. j. o. t. r. (2009). Pro-poor tourism development in Viengxay, Laos: Current state and future prospects. 14(2), 153-168.

15. Tie, W. (2008). The research on the pattern of small scale eliminating poverty by touris based Pro-poor tourism (PPT). Lanzhou University,

16. Zarandian, N., Shalbafian, A., Ryan, C., \& Amin Bidokhti, A. (2016) Islamic pro-poor and volunteer tourism - The impacts on tourists: A case study of Shabake Talayedaran Jihad, Teheran - A research note. Tourism Management Perspectives, 19, 165-169. doi:https://doi.org/10.1016/j.tmp.2015.12.005

17. Zeng, B., \& Ryan, C. (2012). Assisting the poor in China through tourism development: A review of research. Tourism Management, 33(2), 239-248. doi:https://doi.org/10.1016/j.tourman.2011.08.014

\section{AUTHORS PROFILE} \begin{tabular}{c|c}
$\begin{array}{c}\text { Author-1 } \\
\text { Photo }\end{array}$ & $\begin{array}{l}\text { Wei YANG, Faculty of Humanities and Social Sciences, } \\
\text { International College, Khon Kaen University, Khon Kaen, }\end{array}$
\end{tabular} Thailand
Author-2 Photo

Author-3 Photo
Assoc. Prof. Dr. Sukanya Aimimtham, Public Administration Department, Faculty of Humanities and Social Sciences, Khon Kaen University, Khon Kaen, Thailand.

Dr. Chuanchen BI, Tourism Management Department, International College, Khon Kaen University, Khon Kaen, Thailand 